(n)

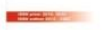

Volume (68) June 2021

\title{
The Invocation of State of Necessity Defense to justify Covid-related Measures Before International Centre for Settlement of Investment Dispute (ICSID)
}

\author{
Abd Almohsen Alajmy \\ LLM student at Georgetown Law Center - Georgetown Law School \\ Email: Ama467@Georgetown.edu
}

\begin{abstract}
The Coronavirus Disease 2019 (Covid-19) pandemic has forced countries to adopt a number of regulatory defensive measures, which, in turn, could negatively impact foreign investors. Therefore, many conceive that foreign investors might recourse to ICSID to initiate investor-State claims against host states under different bilateral investment treaties (hereinafter BIT). The Covid-19 pandemic has badly affected Kuwait, forcing it to adopt a national lockdown to slow down the transmission of the disease.

The lockdown has remained in place for several weeks causing a number of layoff of employees, and companies to declared bankrupt. In this context, this article argues that if UCSID claims are initiated against Kuwait, Kuwait will be able to defend its Covid-19- related measures under the BIT defenses, particularly it can invoke the necessity defense through non-precluded measures provision (hereinafter NPM).
\end{abstract}

Keywords: State of Necessity Defense, Covid-related Measures, ICSID. 


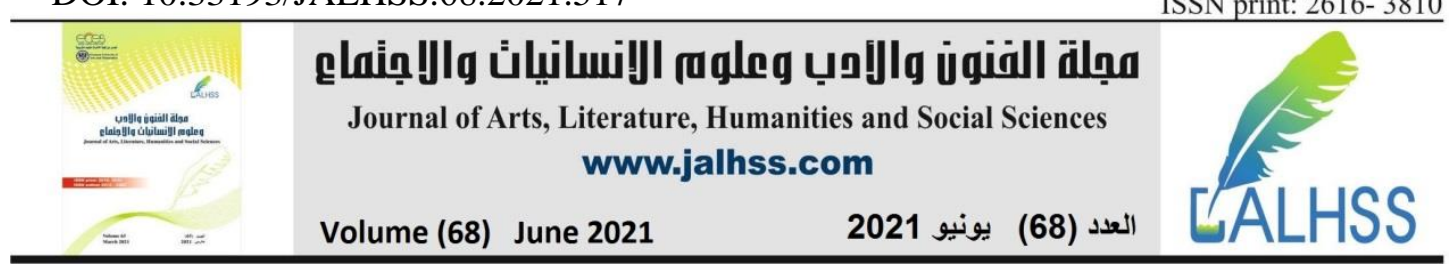

\section{Introduction}

(Covid-19) has been the worst pandemic in the last century. It has resulted in the death of hundreds of thousands of people around the globe ${ }^{1}$ and has caused countless of economic and social misery. ${ }^{2}$ In order to reduce the number of the confirmed Covid-19 cases, many countries have adopted extreme measures. A common measure that countries have adopted is to issue a lockdown order to make people stay at home to impose physical distancing to prevent the transmission of the infection.

These lockdowns have triggered significant social and economic disruptions, as people are unable to consume and buy various goods and services, which, in turn, led to employees layoffs, and dropped the profits and investment of several businesses. ${ }^{3}$ To ensure adequate and sufficient medical supplies, some countries, as emergency responses, have nationalized hospitals. ${ }^{4}$ Other countries like the United States (US) have adopted emergency precautionary steps to empower the production of ventilators that may be needed to treat people affected by Covid-19, under the Defense Production Act. ${ }^{5}$

The Covid-19 pandemic and the regulatory responses by the countries have led many to encourage foreign investors to sue host states through the investor-State dispute settlement (ISDS) mechanism under bilateral investment treaties (BITs). ${ }^{6}$ Apparently, Peru has faced the first warning of an ICSID claim over Covid-19-related measure. ${ }^{7}$

The question this article attempts to answer is whether host-states, Kuwait in particular, can invoke state of necessity defense to justify Covid-19-related measures.

\footnotetext{
${ }^{1}$ WHO Coronavirus Disease (COVID-19) Dashboard <https://covid19.who.int/> (last visited 18 Feb 2021).

2 Maryla Maliszewska Aaditya Mattoo and Dominique van der Mensbrugghe, 'The Potential Impact of Covid-19 of GDP and Trade: A Preliminary Assessment, Policy Research' (2020) World Bank Working Paper No. 9211 <https://open knowledge.worldbank.org/handle/10986/33605> (last visited 18 Feb 2021).

3 Ben Wick, 'The IMF says its forecast for the COVID-19 recession might now be too optimistic' World Economic Forum (18 April 2020) https://www.weforum.org/agenda/2020/04/imf-economycoronavirus-covid-19-recession (last visited 18 Feb 2021).

4 Adam Payne, 'Spain has Nationalized all of its Private Hospitals as the Country goes into Coronavirus Lockdown' Business Insider (16 March 2020) <https://www.businessinsider.in/politics/news/spain-has-nationalized-all-of-itsprivate- hospitals-as-thecountry-goes-into-coronavirus-lockdown/articleshow/74658200.cms> (last visited 12 Feb 2021).

5 Memorandum from President Donald Trump to the Secretary of Health and Human Services (27 March 2020) https://www.whitehouse.gov/presidential-actions/memorandum-order-defenceproduction-act-regarding-general motorscompany/ (last visited 12 Feb 2021).

6 Oliver Hailes, 'Epidemic Sovereignty? Contesting Investment Treaty Claims arising from Coronavirus Measures' EJIL: Talk! (27 March 2020) <https://www.ejiltalk.org/epidemic-sovereigntycontesting-investment-treaty-claims-arising-fromcoronavirus- measures/> (last visited 12 Feb 2021).

7 Cosmo Sanderson, 'Peru warned of potential ICSID claim over Covid-19 measures' Latin Lawyer (15 April 2020) https://latinlawyer.com/article/1225491/peru-warned-of-potential-icsid-claims-overcovid-19-measures (last visited 12 Feb 2021).
} 


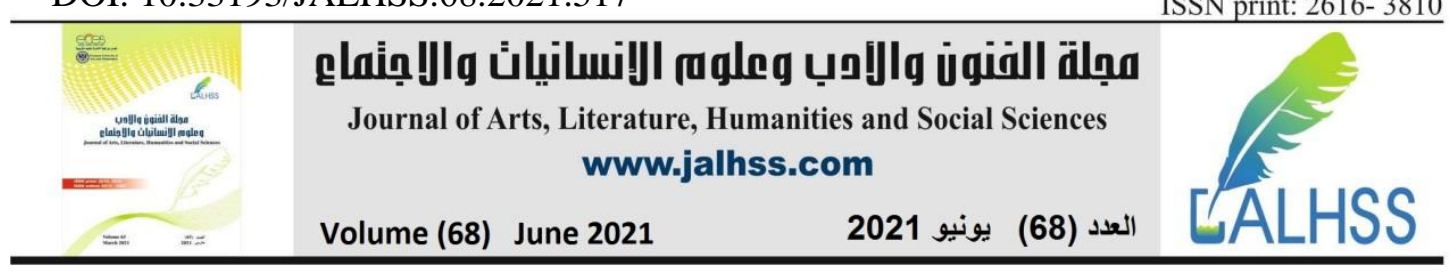

In particular, the national lockdown that has lasted for several weeks, which are challenged under the BITs. ${ }^{8}$

To answer the question that this article is divided into three parts. Part II of the article gives an overview of the state of necessity defense in three sections. First, I will shed light on the definition of the necessity defense under the customary international law, second will be dedicated to the legal framework of this defense, last section will clarify the functionality and legal impact of this invoking this defense. In part III, I will analyze the Non-Precluded Measures (NPM) as it is closely related to the application of the state of necessity defense. This part consists of three sections. First, I will analyze the relationship between the necessity defense and NPM, second will be devoted for the structural elements of the NPM doctrine, third section will articulate the standard of review applicable to the NPM provisions. Last, part VI will attempt to examine the standard of review applicable to the NPM.

\section{II.State of Necessity}

In order to comprehensively discuss the state of necessity defense, I found it important to present the definition of the necessity first, then the structural elements of this defense.

\section{A. Definition}

The necessity has been recognized as a costumery international law rule by ICJ and codified in Article 25 of the Responsibility of States for Internationally Wrongful Acts as one of circumstances which precludes the wrongfulness character of the act conducted by a state. ${ }^{9}$

According to Article 25, a state cannot invoke the necessity defense to justify a violation to international obligation, unless the state's action is the only way to safeguard an 'essential interest against a grave and imminent peril' and did not 'seriously impair an essential interest' of that state, other states, or the international community. ${ }^{10}$ Although Article 25 does not cover damages to private entities, the ILC

${ }^{8}$ Kuwait Covid-19 restrictions: https://www.garda.com/crisis24/news-alerts/438336/kuwait-severalcovid-related restrictions-remain-in-place-in-kuwait-as-of-feb-3-update-29. (last visited 16 Feb 2021).

${ }^{9}$ The final adopted version of its text looked as follows,

1. Necessity may not be invoked by a State as a ground for precluding the wrongfulness of an act not in conformity with an international obligation of that State unless the act:

(a) Is the only way for the State to safeguard an essential interest against a grave and imminent peril; and

(b) Does not seriously impair an essential interest of the State or States towards which the obligation exists,

or of the international community as a whole.

2. In any case, necessity may not be invoked by a State as a ground for precluding wrongfulness if:

(a) the international obligation in question excludes the possibility of invoking necessity; or

(b) the State has contributed to the situation of necessity.

Crawford, James, Draft Articles on Responsibility of States for Internationally Wrongful Acts with Commentaries,

(2001), 80.

${ }^{10}$ Sweet, Alec Stone, Investor-state Arbitration: proportionality's New Frontier, 4 LAW \& ETHICS

HuM. RTS, (2010), 47, 69. 


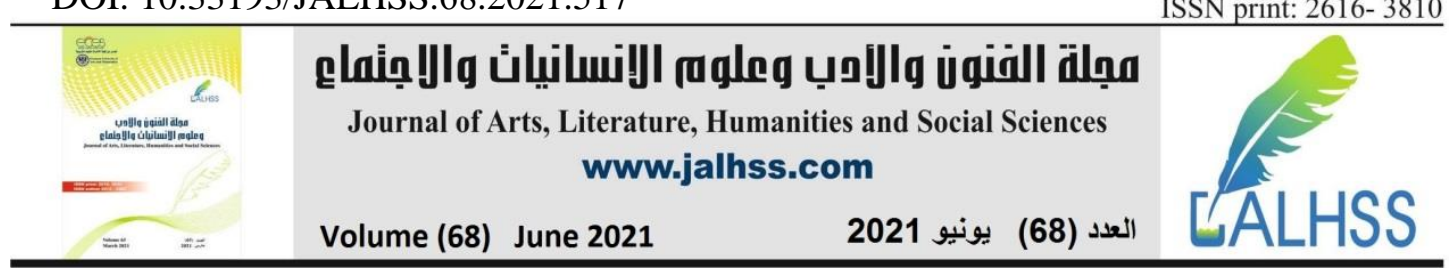

has recognized, through commentary, the applicability of the article to private entities. ${ }^{11}$

According to the ILC commentaries, the term 'necessity' refers to a set of exceptional circumstances where a state, or the international community as a whole, can safeguard an essential interest threatened by a grave and imminent peril, may not, temporarily, comply with some international obligations. ${ }^{12}$ The motive, therefore, behind the violation to an international obligation is to protect an interest of more value. ${ }^{13}$ As a circumstance precluding a state's wrongful act from liability, Necessity involves a situation where a state, or a group of states, acting unilaterally tackling an emergency situation that had not been foreseen by the law when the act was taken.

\section{B. The Elements of State of Necessity Defense}

The state of necessity defense consists of five elements. First, the endangered interest must be essential, second the threat to this interest should be grave and imminent, third the measures taken by states must be the only means available to the acting state, fourth this act does not impair an essential interest of another state, last is the state did not contribute to the creation of the necessity situation. I will discuss them as follows:

\section{Essential Interest}

In order for the state to successfully invoke the necessity defense, the interests that are in danger must be essential. The essential character of an interest means "absolutely of an exceptional nature." ${ }^{14}$ To avoid a broad interpretation of the term 'necessity', which may result in a frequent invocation of necessity defense by states, scholars are of the opinion to narrow the scope of this term to the crucial interest of the states, such as political or economic survival. ${ }^{15}$ However, it should be pointed out that these interests do not have to reflect the only essential interest of a state, since there is no recognized standards globally to assess whether a particular interest is essential or not. In this regard, commentators have emphasized that "no a priori definition of an essential interest can be offered." ${ }^{16}$

According to this opinion, the extent to which an interest can be 'essential' depends on many factors, one of which is the situation which the state attempts to tackle. Therefore, the judgement must be based on factual facts rather than predetermined set of circumstances. ${ }^{17}$

\footnotetext{
${ }^{11}$ Crawford, Supra (n 9), 179.

12 Ibid

13 Ibid

14 Ago, Roberto, The Internationally Wrongful Act of the State, Source of International Responsibility, Eighth Report on State Responsibility, Addendum (1980), The ILC Yearbook (1980) Vol. II (1), Doc. A/CN.4/318/Add.5, 5.

15 Ibid, 19.

16 James Crawford, Second Report on State Responsibility: Addendum, (1999) UN Doc

A/CN.4/498/Add.2, at para

214 [Crawford, Second Report]. Available online at:

http://legal.un.org/ilc/documentation/english/a_cn4 498.pdf

(last visited 6 Feb 2021).

17 Ibid.
} 


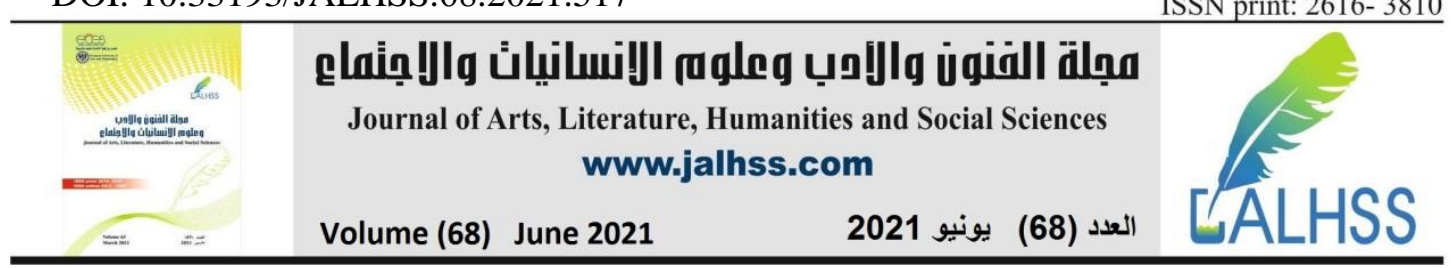

\section{Grave and Imminent Peril}

In order for the state to successfully invoke necessity, it is required to show that it encountered 'a grave and imminent peril'. Put differently, the peril must be seriously threating and endangering the essential interest of the state at the time when the measures was taken. ${ }^{18}$

The threat must occur, the anticipation is not enough to invoke necessity. ${ }^{19}$ Regarding the gravity of the peril, it has been suggested that 'grave peril' can be construed as "any threat likely to destroy the possibility of realizing an essential interest."

In addition to being grave, the peril must be imminent, and the imminent nature of peril has to exist in parallel with peril gravity conditions. ${ }^{21}$

Covid-19 has been recognized as pandemic by the World Health Organization (WHO). ${ }^{22}$ Most of the measures adopted by states have been suggested by WHO to prevent the spread of this disease. The reliance on the assessment of and reports issued by WHO by states is justified as Kuwait and many of states around the world are bound by international obligation to cooperate and comply with international organization to protect public health. ${ }^{23}$

\section{The Only Means}

The third requirement for a successful invocation of necessity defense is the state's measures in question, they must be the 'only means' available to the state to protect its essential interests. ${ }^{24}$ In this context, the ILC clearly stated that a state bears a substantial burden to show there was no other alternatives to safeguard its essential interests except the measure it had adopted. ${ }^{25}$ ILC goes further to ensure that this rule would apply even if the lawful alternatives are more costly or less convenient to the state. ${ }^{26}$ For instance, the ICJ affirmed that the expensive cost of those alternatives could not be considered as a determinative factor in assessing the wrongful act in question under the 'only means' requirement. ${ }^{27}$

Therefore, the state should adopt the appropriate measure even if it would impose extra costs on the state, regardless of the financial solvency of the state, thus the cost cannot be a justification for non-compliance nor a basis for necessity defense. The ILC has emphasized that if a state's action in question does not fall within the scope of 'strictly necessary', it will not survive the only means requirement and will be deemed

\footnotetext{
${ }^{18}$ Ago, supra (note 14), 19.

19 Ibid.

${ }^{20}$ The Neptune, reprinted in IV International Adjudications: Modern Series 372 (John Basset Moore ed., 1931), citedin Roman Boed, "State of Necessity as a Justification for Internationally Wrongful Conduct", (2000) 3(1) Yale

Human Rights and Development Law Journal 1, footnote 28.

${ }^{21}$ Ago, Eighth Report, supra (note 14), 39, footnote 117.

${ }^{22}$ See, https://www.who.int/news/item/29-06-2020-covidtimeline

${ }^{23}$ International Covenant on Economic, Social and Cultural Rights, art 12.2.

${ }^{24}$ Crawford, Supra (n 9), 83

25 Ibid.

26 Ibid.

27 Gabčíkovo-Nagymaros (n 18) para 55.
} 


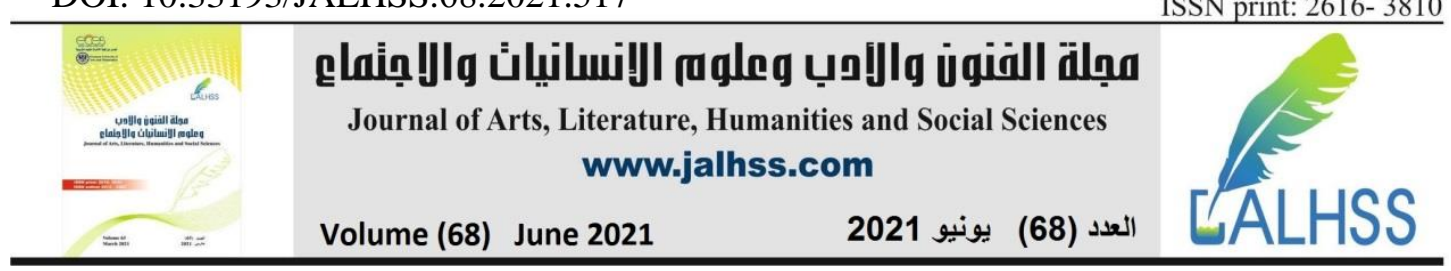

a wrongful act. ${ }^{28}$ This encompasses not only the unilateral actions of a state, but also actions adopted in cooperation with other states or international organizations. ${ }^{29}$

This requirement may raise some issues as the measures adopted by Kuwait, during Covid-19 pandemic, vary and might be challenged. There are no clarifications on the only means requirement by either IJC or ICSID, however WTO appellate body have ruled in a similar case and confirmed that the health-related measures will be subject to objective assessment ${ }^{30}$ and the measures must be based on scientific evidence. ${ }^{31}$ If ICSID assesses the measures with the same standard as the appellate body, the burden of proof would be on the investors, however the proof will not be held to a strict scrutiny because that will be difficult for the investors to use this requirement to prove a breach on the part of Kuwait since there are no certain right measures should be taken as state undertook these steps according to medical scientists' guidelines,. Moreover, all options available to states will result in negative impacts on investors anyway.

\section{Impairment of Essential Interests of Other States}

The last requirement to a successful invocation of the necessity defense is that the act at issue must not seriously impair an essential interest of the other state or states concerned, or of the international community as a whole.

In demonstrating this requirement, the ILC stated that, "the interest relied on must outweigh all other considerations, not merely from the point of view of the acting State but on a reasonable assessment of the competing interests, whether these are individual or collective." ${ }^{32}$

Particularly, the interests of a victim state have to be less important compared to the essential interests of the state invoking the state of necessity defense. ${ }^{33}$ The state will not meet the balancing requirement if its essential interest is equally essential to the interests of the victim state.

This test should not be an issue for Kuwait since the public health is regarded among the highest interest to all states. Therefore, public health as an essential interest will be of the same interest to other states in case the Covid-related measures are challenged under this requirement.

\footnotetext{
${ }^{28}$ Crawford, Supra (n 9), 83.

29 Ibid.

30 See Joost Pauwelyn, The WTO Agreement on Sanitary and Phytosanitary (SPS) Measures as Applied in the First Three SPS Disputes: EC-Hormones, Australia-Salmon and Japan-Varietals, 2 J. INT'L ECON. L.641 (1999).

${ }^{31}$ Ibid.

${ }^{32}$ Crawford, Commentaries, supra (note 9), 184.

33 The ILC Yearbook (1980), Vol. II (2), Doc. A/35/10 at 39, para 14 [The ILC Yearbook (1980), Vol. II (2)]. Available online at: http://legal.un.org/ilc/publications/yearbooks/Ybkvolumes(e)/ILC 1980_v2_p2_e.pdf (last visited 15
} Feb 2021), 150, para 35. 


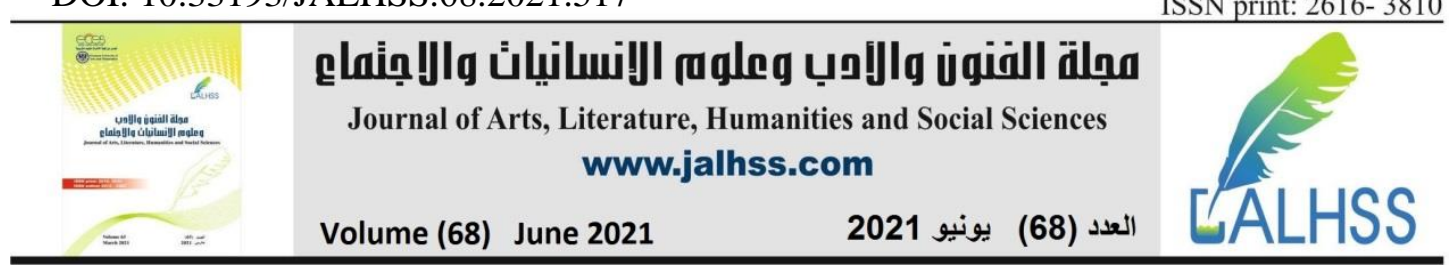

\section{Contribution to a State of Necessity}

Article 25(2)(b) of the ARSIWA also requires that a state has not contributed to the circumstance that triggers the wrongful act. In other words, the wrongfulness of state conduct will not be precluded if the acting state itself contributed to the creation or development of the situation of necessity.

The ILC also emphasized that it does not matter whether a state invoking the necessity defense has contributed to the occurrence of a state of necessity, either intentionally or by negligence. ${ }^{34}$ The ILC further stated that the state's contribution must be "sufficiently substantial and not merely incidental or peripheral.",35

It can be argued that at the beginning of the Covid-19, Kuwait has been negligent in taking precautionary measures to prevent the disease. In fact, in many cases states do contribute to the occurrence or development of necessity situation either negligently or deliberately. Put differently, states do not take precautionary measures beforehand to prevent the situation of necessity from happening, even though they have sufficient resources and time to avoid it. However, it should not be ignored that in some situations, it is difficult for states to foresee the beginning of a pandemic emergency, this is attributed to the requirement of a complex assessment of several scientific factors.

However, if a state has been passive and did not adopt defensive measures to tackle the disease or at least to slow it down, it likely will not be able to survive the contribution to the emergency test. For example, the ICJ did not accept the necessity defense invoked by Hungary. After examining all situations, the tribunal ruled that "even if it had been established that there was, in 1989, a state of necessity linked to the performance of the 1977 Treaty, Hungary would not have been permitted to rely upon that state of necessity in order to justify its failure to comply with its treaty obligations, as it had helped, by act or omission, to bring it about."

Based on this formulation of "contribution", it can be concluded that the burden of proof will be on the respondent state invoking the state of necessity, therefore the state cannot rely on necessity to preclude its wrongfulness act unless it substantiates that it had not 'helped, by act or omission to bring about' that circumstance of necessity.

\section{The Functionality of State of Necessity Defense}

As discussed, the necessity of sate defense precludes the wrongfulness act of the state according to Article 25 of ARSIWA. Therefore, the successful invocation of this defense does not mean "strike down the obligation, and the underlying source of obligation, the primary rule, is not affected by them as such." 37 To clarify, the state of necessity defense does not trigger the termination of the obligation at issue. Consequently, successful invocation of necessity defense precludes the wrongfulness character of the act but does not result in annulling or terminating the obligation.

\footnotetext{
${ }^{34}$ Ibid, para 34.

${ }^{35}$ Crawford, Commentaries, supra (note 9), 185.

${ }^{36}$ Gabčíkovo-Nagymaros, supra (note 10), 46, para 57.

${ }^{37}$ Crawford, Commentaries, supra (note 9), para 224.
} 


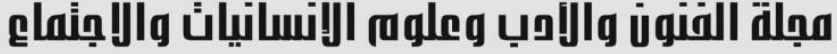 \\ Journal of Arts, Literature, Humanities and Social Sciences www.jalhss.com \\ Volume (68) June 2021 \\ العدد (68) يونيو 2021}

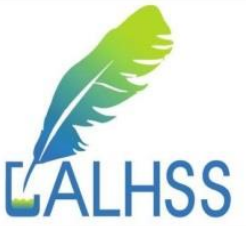

Rather, it functions as a justification or an excuse for non-performance of the obligation at issue for certain period of time when that situation occurred. ${ }^{38}$

\section{Non-Precluded Measures (NPM) in BIT Agreements}

\section{A. The Relationship Between Non-Precluded Measures and State of Necessity}

The terms of NPM and necessity can be conflated. For instance, in construing Article XI of the U.S.-Argentina BIT, the CMS, Sempra and Enron tribunals relied on the requirements of the state of necessity defense, therefore conflated these two defenses. The annulment committees later looked into this issue and resolved it based on their authority under Article 52 of the ICSID Convention. ${ }^{39}$

For the first time, the CMS annulment committee addressed this issue. Its findings separated the basis of NPM and necessity and functions as a guidance for the tribunals. Argentina claimed, before the CMS annulment committee, that the CMS tribunal erred by exceeding its power since it had not applied the NPM clause (Article $\mathrm{XI}$ ) of the U.S.-Argentina bilateral investment treaty and failed to clarify the reasons of its decision. ${ }^{40}$ The committee opined that both disputing parties and the tribunal had 'conflated' the NPM clause and the necessity defense as a customary law, by applying the requirements of necessity to interpreting the NPM. ${ }^{41}$

The committee mainly clarified the relationship between Article XI of the BIT and Article 25 of ARSIWA with respect of their application. After the committee introduced the distinction between primary and secondary rules, it specified how these two defenses must be applied by investment tribunals. ${ }^{42}$ The committee, further, interpreted Article XI as a primary rule of international law (lex specialis). Relying on the ICJ's holding in the Oil Platforms case, ${ }^{43}$ the committee held that, "if the Tribunal was satisfied by the arguments based on Article XI, it should have held that there had been 'no breach' of the BIT." 44

38 Crawford, James, The International Law Commission's Articles on State Responsibility: Introduction, Text and

Commentaries (Cambridge University Press, 2002), 184 [Crawford, ILC Articles],160.

${ }^{39}$ Andreas Von Staden, "Towards Greater Doctrinal Clarity in Investor-State Arbitration: The CMS, Enron, and Sempra Annulment Decisions", Law and Economics Research Paper Series, Working paper No. 2010-13 (November 2010), available online: http://ssrn.com/abstract=1725909 (last visited $17 \mathrm{Feb}$ 2021).

40 ICSID Case No.ARB/01/8; Enron Creditors Recovery Corp. Ponderosa Assets. LP v Argentine Republic, (30 July 2010) Decision on Annulment, ICSID Case No.ARB/01/3 [Enron Annulment]; Sempra Energy Int'l v Argentine Republic, (29 June 2010) Decision on Annulment, para36.

${ }^{41}$ Ibid, 123.

${ }^{42}$ S.R. Subramanian, "Too Similar or Too Different: State of Necessity as a Defense under Customary International Law and the Bilateral Investment Treaty and their Relationship", (2012) 9 (1) Manchester Journal of International Economic Law, 68, para 133.

${ }^{43}$ Case Concerning Oil Platforms (Islamic Republic of Iran v. United States), Judgement, (6 November 2003) Judgement, ICJ, at 196, para 73 [Oil Platforms], available online at: http://www.icjcij.org/docket/files/90/9715.pdf (last visited $19 \mathrm{Feb} 2021$ ).

${ }^{44}$ See CMS Gas Transmission Co v The Argentine Republic, (25 September 2007) Annulment Decision, ICSID Case No.ARB/01/8. 


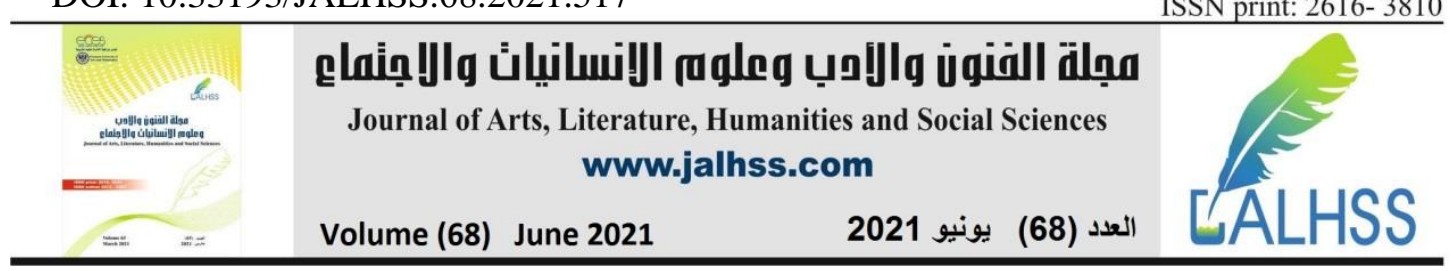

Regarding Article 25, the committee, identified it as a secondary rule ${ }^{45}$ and ruled that, "the excuse based on customary international law could only be subsidiary to the exclusion based on Article XI." ${ }^{, 46}$ In other words, the CMS annulment committee suggested that the tribunal may first consider whether an act cannot be considered a potential treaty breaches by a treaty NPM provision (Article XI) that is applied as lex specialis, and then it should consider Argentina precluded from liability for a breach under customary international law (Article 25) applied as lex specialis.

In its analysis, the committee differentiated the two defenses and pointed out that Article XI "covers measures necessary for the maintenance of public order or the protection of each Party's own essential interests, without qualifying such measures......while Article 25 subordinates the state of necessity to four conditions" 47

\section{B. The Structure of Non-Precluded Clauses}

Before discussing the standard of review of NPM, it is important to understand the structural components of NPM clauses. In this section, I will shed light on the structural elements of NPM clauses, which will function as a basis for our analysis to determine the proper standard of review.

Despite the slight differences in the formulation of NPM clauses in the bilateral investment treaties of various countries, they include similar attributes. NPM clauses, in general, contain the following attributes: 1) Nexus requirement; 2) Scope; 3) Permissible objectives. ${ }^{48}$

\section{The Nexus Requirement}

First, NPM clauses provide for a nexus requirement. This condition imposes on the measures that are adopted by a state to be appropriately related to the permissible objectives enumerated in the clause. In other words, there must be a link between the measures taken by a state and the permissible objectives set forth in the clause. For instance, the NPM clause of the U.S.-Argentina BIT $^{49}$ requires that measures adopted by states correspond to one of permissible objectives set forth in the clause and be 'necessary' to achieve the objectives.

In the same context, the measures cannot be covered by the clause if the state has an alternative and more convenient measure to attain the objective. As can be seen, the term 'necessary' is a requirement of the nexus requirement in the NPM clause of the U.S.-Argentina BIT. However, NPM clauses in other BITs contain different languages regarding the nexus requirement. They contain formulations such as

\footnotetext{
45 See ILC, Report of the Study Group of the International Law Commission, Fragmentation of International Law: Difficulties Arising from the Diversification and Expansion of International Law (4 April 2006), Doc. A/CN.4/L.682 [ILC Fragmentation Report], online at: http://legal.un.org/ilc/documentation/english/a_cn4_1682.pdf (last visited 25 Feb 2021).

${ }^{46}$ CMS Annulment, supra (note 37), para 132.

47 Ibid, para 130.

${ }^{48}$ William W. Burke-White, "The Argentine Financial Crisis: State Liability under BITs and the Legitimacy of

ICSID System", (2008) 3 Asian Journal of WTO and International Health Law and Policy 199, 206.

${ }^{49}$ U.S.-Argentina BIT (1994), Article II, signed 14 November 1991; entered into force 20 October 1994. Available online: http://investmentpolicyhub.unctad.org/Download/TreatyFile/127.
} 


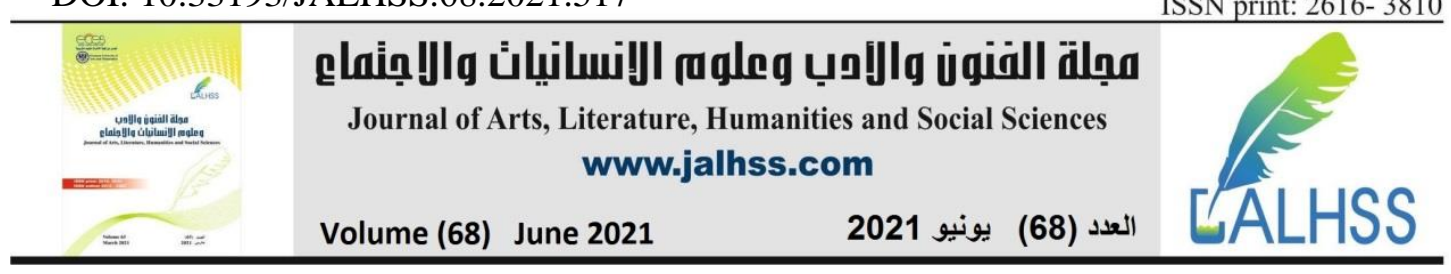

"require", " 50 "directed to" "51 and "have to be taken for reasons of." the nexus requirement functions as vital link between the taken measures and the permissible objectives in the NPM clause.

These formulations provide for a framework of a reasonable and non-abusive application of these measures. Various languages used in the nexus requirement can establish various frameworks offering host states different levels of freedom in taking measures to attain the permissible objectives.

As opposed to the language of 'necessary', nexus requirements with lenient standards of language provide states a wider scope of freedom to react to emergency situation and offer more opportunities for a successful invocation of NPM clauses.

Second, states that incorporate the NPM clauses in BITs usually specify the scope of their applicability to the provisions of BITs. The specification can be broad, encompassing all treaty obligations, or narrow, including only certain substantive provisions of the treaty. The NPM clauses in Indian BITs are illustrative examples of broadly formulated and applied to preclude violation of any substantive provision of the treaty. For example, the NPM clause in the India-China BIT states that "nothing in this Agreement precludes the host Contracting Party from taking action for the protection of its essential security interests..."53 In this NPM clause, this formulation indicates that the clause has a broad scope and applies to all obligations resulting from the treaty. ${ }^{54}$

In comparison, some BITs provide for limited scope. For instance, German BITs NPM clauses are drafted in limited scope, the application of these clauses precludes the violation of only some treaty obligations specified by the parties. ${ }^{55}$ Therefore, a state that has taken measures 'for reasons of' achieving public policy objectives such as public security and order, public health or morality will not bear liability with respect to violating the aforementioned treaty obligations.

It should be noted that the scope of the clause does not extend to all obligations under the treaty and is limited only to three specific articles (obligations) of the BIT, which are fair and equitable treatment, national and most-favored nation treatment. Therefore, a state that adopted measures contrary to the treaty will be liable for its actions if they violate treaty obligations other than the abovementioned three obligations. $^{56}$

There are also NPM clauses restricting both the scope of the treaty's responsibilities and permissible objectives. The example of this type would be the Uganda-Belgium-

\footnotetext{
${ }^{50}$ Lebanon-Belgium-Luxemburg BIT (1999) Article 3(3).

${ }^{51}$ Sri-Lanka-China BIT (1986) Article 11.

52 Germany-Bangladesh BIT (1981) Protocol 2 (a).

53 India-China BIT (2006), Article 14.

54 See, Finland-India BIT (2002) Article 12(2).

55 See Protocol to China-Germany BIT (2003), section 4.

${ }^{56}$ The scope of NPM clauses can also be limited to other treaty provisions such as expropriation or nationalization (Belgian-Luxemburg-China BIT).
} 


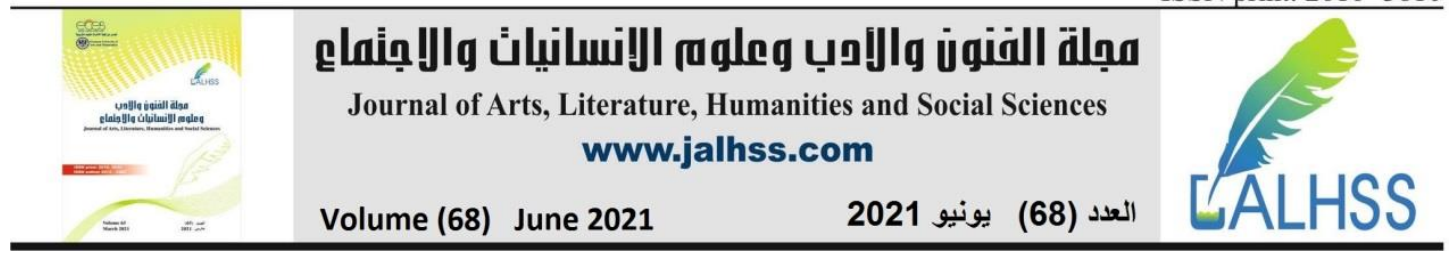

Luxemburg BIT which contains a provision stating that "except for measures required to maintain public order, investments shall enjoy continuous protection and security..."57 On one hand, the provision allows host states to adopt necessary measures only to safeguard and maintain public order, and excludes other emergency circumstances encompassing a state's need to protect public health, environment and other essential security interests.

On the other hand, the scope of the provision is limited only to that particular treaty obligation to ensure continuous protection and security under the provision of fair and equitable treatment. According to this NPM clause, in order to preclude liability, a host state can impose measures directed only at protecting public order. The adoption of measures directed at achieving other public policy objectives such as public health and environment cannot be justified under this clause and will eventually trigger state liability.

Additionally, the state measures taken to protect public order may preclude state's liability only with respect to the treaty obligation of providing fair and equitable treatment for foreign investments. However, it may not preclude state's liability for violating any other obligations under other treaty, for example national and mostfavored nation treatments, even if the imposed measures were directed at protecting public order, and not other public policy objectives.

It should be pointed out that if states want to have more freedom and flexibility in protecting their public policy objectives, they may incorporate NPM clauses with wider scope that could apply to all treaty obligations. Conversely, if states want to grant a greater protection to foreign investors, they can draft the NPM clauses with narrower scope that only apply to certain obligations under the treaty.

\section{The scope of Non-Precluded Clauses}

The last element of the NPM clause is the permissible objectives, which are considered the motive behind the adoption of measures contrary to state's treaty obligations. Permissible objectives cover particular public policy aspects that states consider essential to be protected. These public policy areas are excluded from limitations imposed by the treaty obligations. Thus, states are usually offered a great deal of freedom in adopting measures directed at attaining the permissible objectives set out in the NPM clause. Put differently, state's actions directed at achieving public policy objectives specified in the NPM clause shall be considered permissible even if they contradict the obligations established in the treaty. Since permissible objectives "delineate the boundaries of state sovereignty that will not be compromised by the state's IIA Obligations", 58 the nature and language of this element of the NPM clause is deemed to be crucial. Public policy objectives in the context of protecting public

\footnotetext{
${ }^{57}$ Uganda - Belgium-Luxembourg BIT (2005), Article 3(2).

58 Barnali Choudhury, "Exception Provisions as a Gateway to Incorporating Human Rights Issues into International Investment Agreements", (2010-11) 49 Columbia Journal of Transnational Law 670, 688.
} 


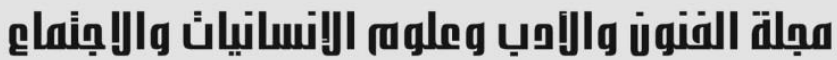 \\ Journal of Arts, Literature, Humanities and Social Sciences www.jalhss.com \\ Volume (68) June 2021 \\ العدد (68) يونيو 2021

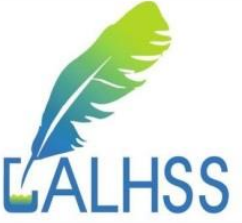

order, health, morality, security and other essential state interests are considered as permissible objectives in most BITs. ${ }^{59}$

C. Standard of review

\section{Self-Judging}

Self-judging clauses can be defined as clauses that permit states to reserve themselves a right of non-compliance with international obligations in situations when the state considers that the compliance will affect their sovereignty, security, public policy, or more generally, their essential interests. ${ }^{60}$ Based on such clauses, a state has the right to declare particular treaty obligations, on a unilateral basis, as non-binding, if, based on its own subjective determination, that treaty obligations will affect its essential interests at issue. $^{61}$

Therefore, in light of the self-judging clauses, a state is granted a discretion to derogate from international obligations for the domestic interests. ${ }^{62}$ The formulation of the self-judging NPM varies in almost every IBT. For instance, it may be formed as 'if the state considers', and this language would determine the self-judging nature of the clause. Self-judging clauses have been classified by scholars into four types: 1) clauses concerning the restriction of, or derogation from, international obligations; 2) clauses permitting exit from an entire treaty regime; 3) clauses providing for limitations to the consent of states to international dispute settlement; 4) clauses concerning reservations to international treaties. ${ }^{63}$

The self-judging clauses found in BITs regimes mainly fall under the first category. Examples of Self-Judging Clauses in Investment Agreements. in U.S. and Canadian BITs signed after 2004. ${ }^{64}$ Moreover, in U.S.-Uruguay BIT (2005) Article 18 (2) states:

Nothing in this Treaty shall be construed: ... to preclude a Party from applying measures that it considers necessary for the fulfillment of its obligations with respect to the maintenance or restoration of international peace or security, or the protection of its own essential security interests. ${ }^{65}$

The investor-state arbitration tribunals have opined that self-judging NPM clauses do not prevent the tribunal from review the case, but rather, lower the standard of review from substantive to good faith analysis. For instance, in the Argentine cases the arbitral tribunals, opined that despite the fact that they had been tasked with assessing

\footnotetext{
${ }^{59}$ See Article XI, the U.S.-Argentina BIT (1994).

${ }^{60}$ Susan Rose-Ackerman \& Benjamin Billa, "Treaties and National Security", (2008) 40 New York University Journal of International Law and Politics, 437.

${ }^{61}$ See Stephan Schill \& Robyn Briese "If the State Considers: Self-Judging Clauses in International Dispute Settlement", (2009) 13 Max Plank Yearbook of United National Law, 67.

${ }^{6}$ Ibid, 64.

${ }^{63}$ Ibid, 81

${ }^{64}$ U.S.-Bahrain BIT (September 19, 1999), Article 14

${ }^{65}$ Article 18(2), the U.S.-Uruguay BIT (November 4, 2005).
} 


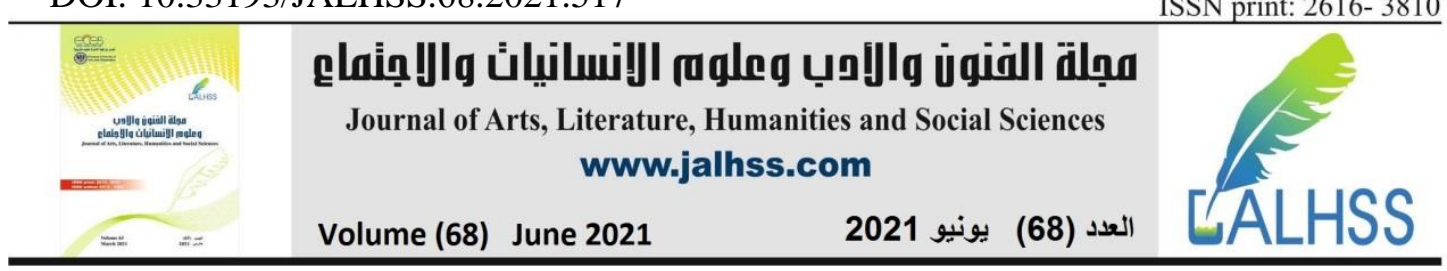

Argentina's measures under a self-judging NPM clause of the U.S.-Argentina BIT, they would hold the measures to the good faith. ${ }^{66}$

\section{Non Self-Judging}

Non-self-judging NPM clauses, primarily those related to essential security, appears when the drafting technique of the BIT does not imply the level of deference that should be afforded to the invocation of exceptions. Therefore, the IIA must be subject to the substantive review, and that will be subject to the interpretation of arbitrators. As a result, a state is given no discretion to make their own determination. Language to this effect is 'measures necessary for' or 'taking action for'. ${ }^{67}$ In such circumstances, the arbitral tribunal would be tasked with assessing whether a measure were, in fact, adopted by virtue of the necessity for the protection of essential security interests.

\section{Permissible objectives under Kuwaiti BITs justifying Covid-related measures}

In order to successfully invoke the NPM clause to justify Covid-related measures, Kuwait must adopt measures that are under one of four public policy objectives. If the measures are not directed at attaining the permissible objectives set forth in the clause, they are not justified, therefore the Kuwait's liability will not be precluded in case there has been a damage done to foreign investments. Kuwaiti rights in adopting health-related measures present in some BITs. These IBTs, mainly, fall under six categories; first is the circumstances of extreme emergency, two is health; three is public purpose; four is legislation; five is national interest; six is public interes.. We will discuss security as it is expansive in nature to cover health emergency situation.

\section{Circumstances of extreme emergency:}

The term Circumstances of extreme emergency allows state to enforce measures, in violation of their BIT's obligations, to contains the emergency situation. This objective occurs in the BIT between Kuwait and India. Article 14.2 of the KuwaitIndia BIT provides:

Nothing in this Agreement precludes the host Contracting State from taking necessary reasonable measures in accordance with its laws applied generally on a non-discriminatory basis, in circumstances of extreme emergency for the specific purposes of prevention of diseases or pests. ${ }^{68}$

It should be noted that circumstances of extreme emergency is not a permissible objective. It actually means circumstances that are of severe emergency where Kuwait can derogate from its BIT obligations. Therefore, it essentially includes certain circumstances, and not an objective like an 'essential security interest'. ${ }^{69}$ But, in this context circumstances of extreme emergency is a permissible objective since it may encompass different regulatory objectives within its scope. This provision will allow Kuwait to deviate from its BIT obligations for any emergency circumstances, whether

\footnotetext{
${ }^{66}$ LG\&E Energy Corp. v. Argentine Republic, ICSID Case No. ARB/02/1, Decision on Liability, (Oct. 3, 2006), para 214.

${ }^{67}$ Newcombe and Paradell, Law and Practice of Investment Treaties: Standards of Treatment (Kluwer Law International BV 2009), 495.

${ }^{68}$ India-Kuwait BIT (2002), art 14.2

${ }^{69}$ Prabhash Ranjan, 'India's International Investment Agreements and India's Regulatory Power as a Host Nation' (PhD thesis, Kings College, London 2013).
} 


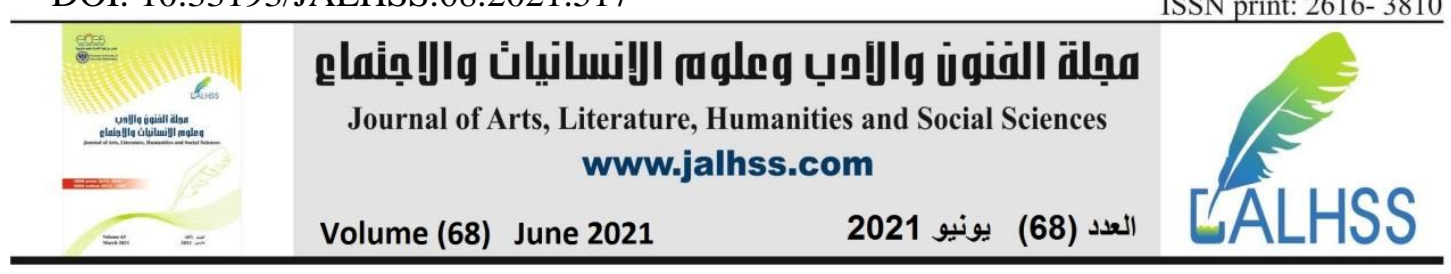

related to strict security-related interests or non-security related interests, upon the satisfaction of the high threshold of 'extreme emergency'. The global Covid-19 pandemic is undoubtedly one of these circumstances, which will satisfy the requirement of this high threshold. Thus, Kuwait can derogate from its BIT obligations by arguing that the Covid-19 pandemic can be considered a situation of extreme emergency.

\section{Public Health}

The term of public health does not raise that much interpretative ambiguities. ${ }^{70}$ Public health situation shifts the risk to investors to protect public health. ${ }^{71}$ Also, public health stands out as the only permissible objective that is susceptible to objective scientific proof than, for example, the subjective threats to a nation's security.

The question is what scientific requirements have to be satisfied in order for a phenomenon to be regarded a threat to public health and sufficient to successfully invoke the NPM. There may be some easy cases, such as an outbreak of human-tohuman transmitted bird flu. Also, those involving evaluations of whether particular

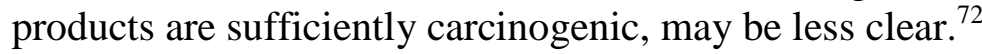

The case law of the WTO/GATT legal regime may offer a clarification on the level of threat necessary to justify public health measures. Article XX(b) of the GATT allows states, subject to the conditions of the chapeau of Article XX,251, to take and enforce measures that might be contrary to the GATT's substantive provisions if these measures are 'necessary to protect human, animal or plant life or health.' The standards for the adoption of these measures have been clarified in the agreements. For instance, on Sanitary and Phytosanitary Measures (SPS Agreement) ${ }^{73}$ Article 2 (2) of the SPS Agreement provides the basic requirement which provides that: "members shall ensure that any sanitary or phytosanitary measure is applied only to the extent necessary to protect human, animal or plant life or health, is based on scientific principles and is not maintained without sufficient scientific evidence, except as provided for in paragraph 7 of Article 5."74 It is evident that Article 3(1) obliges WTO members to assess such measures with 'international standards, guidelines or recommendations,'. If the measures met these standards, they are considered adopted consistently with the GATT.

In several cases brought before WTO Dispute Settlement Body (DSB), the tribunal addressed the specific conditions resulting from the SPS Agreement. The tribunal

70 WILlIAM W. BURKE-WHITE \& ANDREAS VON STADEN, Investment Protection in Extraordinary Times: The Interpretation and Application of Non-Precluded Measures Provisions in Bilateral Investment Treaties, VIRGINIA JOURNAL OF INTERNATIONAL LAW, Vol 48:2, 361.

71 Ibid,

72 See Appellate Body Report, European Communities-Measures Affecting Asbestos and AsbestosContaining Products, 仕 16, 27, WT/DS135/AB/R (Mar. 12, 2001).

73 Agreement on the Application of Sanitary and Phytosanitary Measures., Apr. 15, 1994, Marrakesh Agreement Establishing the World Trade Organization, Annex 1A, 1867 U.N.T.S. 493, available at http://www.wto.org/English/tratop_e/sps_e/spsagr_e.htm (last visited 15 Feb 2021).

${ }^{74}$ Id. art. 2(2). 


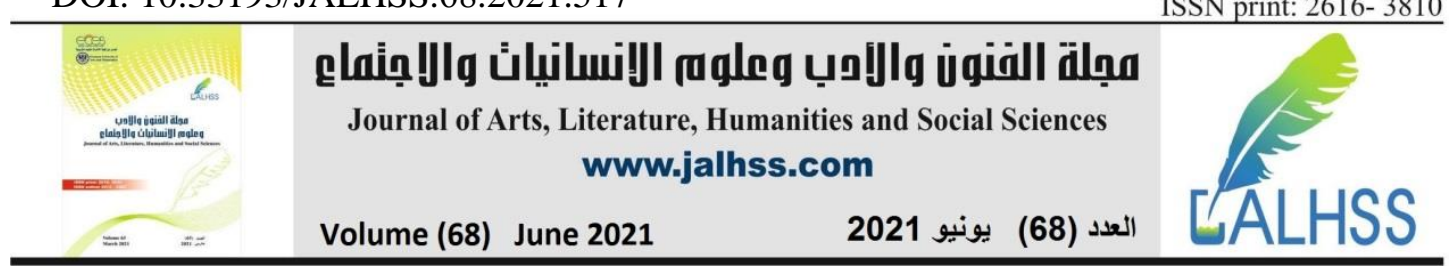

made three important determinations ${ }^{75}$ all of which are related to the interpretation of NPM clauses. First, the Appellate Body confirmed that the proper standard of review at the dispute settlement phase required an 'objective assessment of the facts' in accordance with Article 11 of the WTO DSU, rather than deferring to determinations made by the acting state. ${ }^{76}$ Second, regarding the requirement that the adoption of the measures must be motivated by sufficient scientific evidence, the Appellate Body required that "there be a rational or objective relationship between the SPS measure and the scientific evidence." "77 Third, such 'risk assessments' and the SPS measures adopted does not need to be based on the majority views of the relevant scientists. Rather, it can be based on the minority respected sources 'opinions, as long as they are reasonable and the link between risk assessment and measures adopted is preserved. $^{78}$

The standards have been developed by the WTO, measures must be based on scientific evidence, or appropriate risk assessments, and there must be a rational link between that evidence, or risk assessment, and the measure in question seems to reflect both the ordinary understanding of public health and the acting states should be between the protection of investment and the protection of the health of their citizens. The WTO standard suggests that, where states adopt measures to safeguard public health that are based on respected scientific evidence, the risks and costs of such actions under a BIT shift from the state to investors.

Only few Kuwait BITs contain health as permissible objective in the NPM provisions. However, the formulation and the scope of these NPM provisions vary. For example, Kuwait-Canada BIT Article 17 (1) (a) provides for:

1. Subject to the requirement that such measures are not applied in a manner that would constitute arbitrary or unjustifiable discrimination between investments or between investors, or a disguised restriction on international trade or investment, nothing in this Agreement shall be construed to prevent a Party from adopting or enforcing measures necessary:

(a) to protect human, animal or plant life or health; ${ }^{79}$

This article is The words, "To protect... health" recognize that the host state is offered a policy space to adopt measures in accordance with its laws which are to be consistently, with other obligations, applied, especially fair and equitable treatment and on a non-discriminatory basis. ${ }^{80}$ It is worth noting that these measures must be necessary to attain the permissible objective (health). The word necessary will allow

75 See, Joost Pauwelyn, The WTO Agreement on Sanitary and Phytosanitary (SPS) Measures as Applied in the First Three SPS Disputes: EC-Hormones, Australia-Salmon and Japan-Varietals, 2 J. INT'L ECON. L.641 (1999).

76 See Appellate Body Report, European Communities-Measures Concerning Meat and Meat Products (Hormones), 116-19, WT/DS26/AB/R \& WT/DS48/AB/R (Jan. 16, 1998)

77 Appellate Body Report, Japan-Measures Affecting Agricultural Products, 84, WT/DS76/AB/R (Feb. 22, 1999).

78 See Appellate Body Report, European Communities-Measures Concerning Meat and Meat Products (Hormones), 116-19, WT/DS26/AB/R \& WT/DS48/AB/R (Jan. 16, 1998)

${ }^{79}$ Kuwait-Canada (2011), art 17.

80 Ibid, 


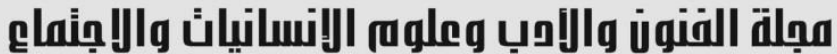 \\ Journal of Arts, Literature, Humanities and Social Sciences www.jalhss.com}

Volume (68) June 2021

2021 يونيو

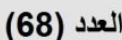

the tribunal to assess the measures with the only means requirement of the state of necessity defense, if these regulatory measures could have been avoided then the invocation of the necessity defense likely will not succeed. For instance, Kuwait adopted number of measures in fighting Covid-19 pandemic, complete and partial curfew, travel restrictions, three months after the government allowed business with restrictions of social distancing. If investors, in challenging the shutdown measures, can prove that the social distancing had been proposed by the same respected scientists the government consulted, the shutdown might a breach committed by the government.

The second example of health as a permissible objective is Article 14.2. of the BIT signed between Kuwait and India for "prevention of disease or pest"" which provides: Nothing in this Agreement precludes the host Contracting State from taking necessary reasonable measures in accordance with its laws applied generally on a non-discriminatory basis in circumstances of extreme emergency for the specific purposes of prevention of diseases or pests. ${ }^{81}$

Despite the fact that the term of public health is not mentioned in this provision, the words 'prevention of diseases' are expansive enough to cover Covid-related regulatory measures. Therefore, Kuwait might invoke this provision to justify its Covid- related regulatory measures.

Despite its common used in most BITs, there is no definition for the term 'public order' in the NPM clauses or other articles of BITs ${ }^{82}$ However, practically in civil law countries, For example, in French law, the term 'public order' means the enacted rules by states to safeguard the fundamental values of society. ${ }^{83}$ It is also considered as encompassing legislative, departmental and judicial requirements that maintain the continuous functions of the state. ${ }^{84}$ In international law, 'public order' is viewed to be "a specific concept directed at preserving the fundamental interests of a given society, which would include the maintenance of the rule of law." 85

Health-related regulatory measures, in my view, can be justified under this objective. The reasons for that is; first, public order had very narrow function which is the maintenance of the state rule of law. Second, the times of Covid-19 pandemic has resulted in many essential regulations that have been enacted to protect health. Third, public health is a fundamental interest in all states.

\section{The Scope of Kuwait Covid-related Measures}

The broad discretion of States to adopt measures for reasons of public health is well established. For instance, the arbitral tribunal in Philip Morris v. Uruguay ruled that measures adopted by Uruguay to regulate tobacco products were not found violative as the bona fide non-discriminatory exercise of the State's 'police powers' to regulate for reasons of public health that did not amount to an indirect expropriation or a

\footnotetext{
${ }^{81}$ Kuwait-India BIT (2002), art 14.2.

${ }^{82}$ Letter of Transmittal, U.S.-Kyrgyzstan BIT, Article X, January 19, 1993, S. Treaty Doc. No. 103-13. Available online at: http://www.state.gov/documents/organization/43567.pdf (last visited 9 Feb 2021).

83 Catherine Kessedjian, "Public Order in European Law", (2007) 1 Erasmus Law Review 25, 26.

${ }^{84}$ MJB Bernier, "Droit Public and Ordre Public", (1929) 15 Transactions of the Grotius Society 83, 84. 85 Ibid.
} 


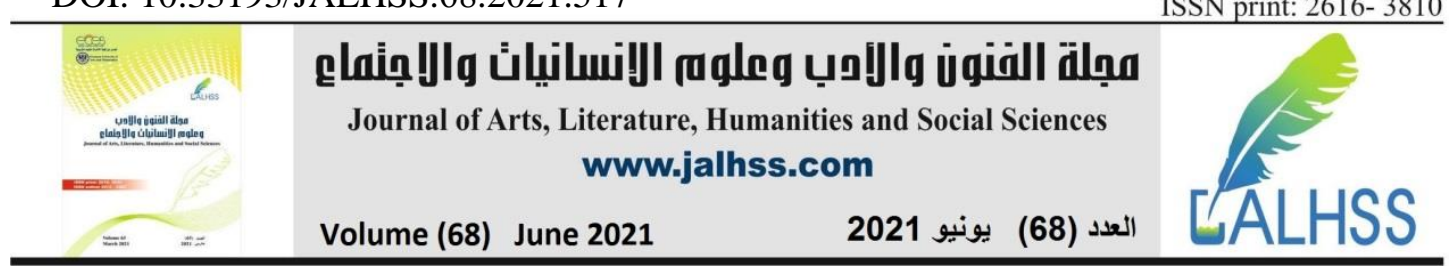

breach of the FET obligation. ${ }^{86}$ The Philip Morris tribunal reaffirmed a State's broad discretion, emphasizing that "investment tribunals should pay great deference to governmental judgments of national needs in matters such as the protection of public health". ${ }^{87}$ In this case, the World Health Organization intervened in support of the public health measures regulated by Uruguay. ${ }^{88}$ Other investment tribunals, notably Chemtura v. Canada and Apotex v. United States, ${ }^{89}$ have reaffirmed the broad discretion of States to enact in the interests of public health.

However, as mentioned before, host countries are allowed to adopt measures to protect the public health but this right is not absolute, it is contingent upon a scientific opinion from a well-respected health scientists and these measures should remain supported by the those scientists. ${ }^{90}$

Kuwait has formed a committee consisting of a number of scientists to evaluate the situation during the pandemic it was tasked to provide the government with necessary measures need to be adopted. ${ }^{91}$ However, there is a question as to the scope and discretion the government has to amend or not to adhere to the measures suggested by the scientists' opinion. In other words, if the committee suggested a particular measure but the government, based on its own vision, decides to go beyond and adopts completely or different measures to achieve the same objective, can the host state in trigger the liability of the host state.? Fore example, this measures curfew in one province of the country but the government estimates that all provinces should be shutdown, would that be a ground for investor-state claim.? Frankly, the permissible health objectives should be protected in light of experts' opinion based on its unique nature if the host state wants to avoid liability, particularly, health as a very complicated science which should be dealt with by experts. Also, if the government of the host country might be able to use the participation of the scientists to escape liability if bad faith exists. ${ }^{92}$

As a restriction on the host-state discretion to adopt health-related measures, developing states are under obligation to establish a strong health system and contain the pandemic to ultimately left the measures in a short time as it has sufficient

86 Philip Morris Brands Sàrl, Philip Morris Products S.A. and Abal Hermanos S.A. v. Oriental Republic of Uruguay, ICSID Case No. ARB/10/7, Award (July 8, 2016), III 306, 420, 434.

87 Philip Morris Brands Sàrl, Philip Morris Products S.A. and Abal Hermanos S.A. v. Oriental Republic of Uruguay, ICSID Case No. ARB/10/7, Award (July 8, 2016), Il 399.

88 Philip Morris Brands Sàrl, Philip Morris Products S.A. and Abal Hermanos S.A. v. Oriental Republic of Uruguay, ICSID Case No. ARB/10/7, Written Submission (Amicus Curiae Brief) by the World Health Organization and the WHO Framework Convention on Tobacco Control Secretariat (Jan. 28, 2015).

${ }^{89}$ See, e.g., Crompton (Chemtura) Corp. v. Government of Canada, UNCITRAL, Award (Aug. 2, 2010), II 266; Apotex Holdings Inc. and Apotex Inc. v. United States of America, ICSID Case No. $\mathrm{ARB}(\mathrm{AF}) / 12 / 1$, Award (Aug. 25, 2014), II 8.75.

${ }^{90}$ Supra, 22-23.

91 https://www.garda.com/crisis24/news-alerts/445301/kuwait-authorities-amend-covid-19-entryrestrictionseffective-feb-21-update-31
92 See TECNICAS MEDIOAMBIENT case No. ARB (AF)/00/2, May 29, 2003. 


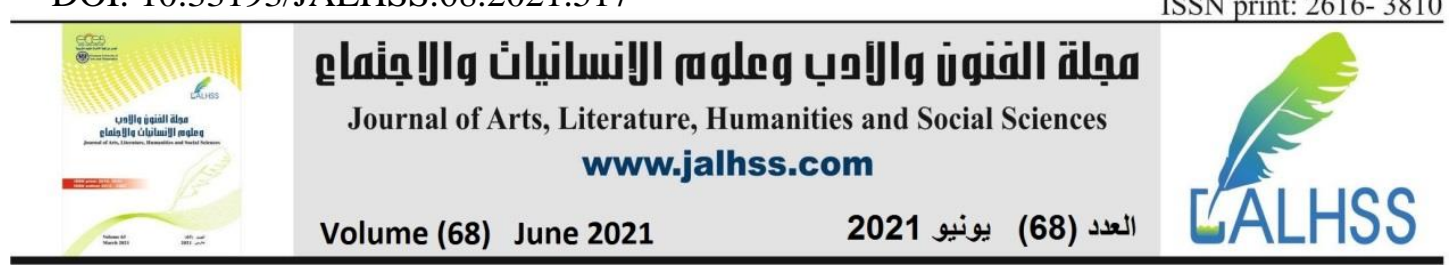

sources, "Extensions may be granted to low resource countries if justified by lack of funding" $"$.

A. The measures taken by the government must be designed to achieve the health objective

A survey has been conducted, sector-specific, on 13 different sectors across Kuwait, to measure the loss, found the following: 1) $36 \%$ of Retails stores have suspended operations, while $46 \%$ had a revenue drop by more than $50 \%$ but were still operating when the survey was conducted; 2) $39 \%$ of Construction sector, Contracting, Architecture have suspended operations, as $31 \%$ of them had a revenue decrease by more than $80 \%$ but were still operating when the survey was conducted; 3) $46 \%$ of Professional Services have suspended operations, while $37 \%$ had a revenue drop by more than $50 \%$ but were still operating when the survey was conducted. ${ }^{94}$

The broad discretion of States to adopt measures for reasons of public health is well established. For instance, the arbitral tribunal in Philip Morris v. Uruguay ruled that measures adopted by Uruguay to regulate tobacco products were not found violative as the bona fide non-discriminatory exercise of the State's 'police powers' to regulate for reasons of public health that did not amount to an indirect expropriation or a breach of the FET obligation. ${ }^{95}$ The Philip Morris tribunal reaffirmed a State's broad discretion, emphasizing that "investment tribunals should pay great deference to governmental judgments of national needs in matters such as the protection of public health". ${ }^{96}$ In this case, the World Health Organization intervened in support of the public health measures regulated by Uruguay. ${ }^{97}$ Other investment tribunals, notably Chemtura v. Canada and Apotex v. United States, ${ }^{98}$ have reaffirmed the broad discretion of States to enact in the interests of public health.

The question here is how many obligations, according to BITs Kuwait is party to, Kuwait under while adopting health-related measures during the pandemic.?

\footnotetext{
93 Tim K. Mackey \& and Bryan A. Liang, “Lessons from SARS and H1N1/A: Employing a WHOWTO forum to promote optimal economic-public health pandemic response The continuation of the measures should be based on scientific opinion", Journal of Public Health Policy Vol. 33, 1, 119-130.

94 Nouf Almazidi, Kuwait COVID-19 Business Impact Survey Finds 45\% of Businesses have Shut Down Since February, available at: https://www.prnewswire.com/news-releases/kuwait-covid-19business-impact-survey-finds-45-of-businesses-have-shut-down-since-february-301060491.html (last visit March 6 2021).

95 Philip Morris Brands Sàrl, Philip Morris Products S.A. and Abal Hermanos S.A. v. Oriental Republic of Uruguay, ICSID Case No. ARB/10/7, Award (July 8, 2016), TII 306, 420, 434.

96 Philip Morris Brands Sàrl, Philip Morris Products S.A. and Abal Hermanos S.A. v. Oriental Republic of Uruguay, ICSID Case No. ARB/10/7, Award (July 8, 2016), II 399.

97 Philip Morris Brands Sàrl, Philip Morris Products S.A. and Abal Hermanos S.A. v. Oriental Republic of Uruguay, ICSID Case No. ARB/10/7, Written Submission (Amicus Curiae Brief) by the World Health Organization and the WHO Framework Convention on Tobacco Control Secretariat (Jan. 28, 2015).

98 See, e.g., Crompton (Chemtura) Corp. v. Government of Canada, UNCITRAL, Award (Aug. 2, 2010), 266; Apotex Holdings Inc. and Apotex Inc. v. United States of America, ICSID Case No. ARB(AF)/12/1, Award (Aug. 25, 2014), 8.75.
} 


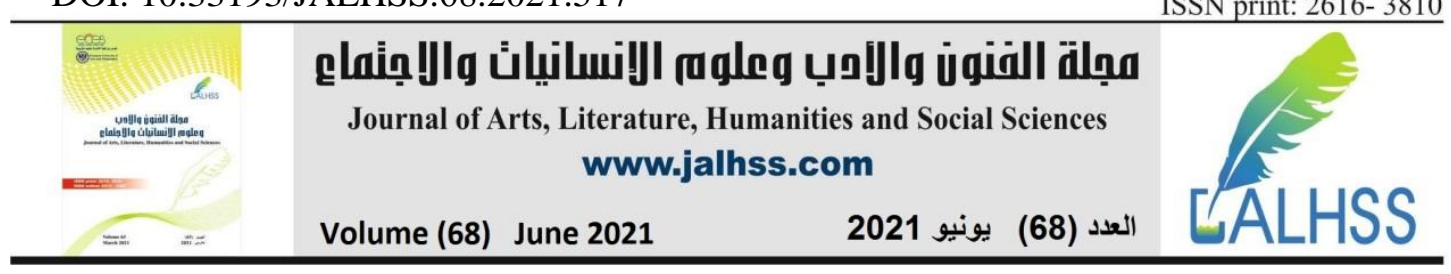

By way of example, Article 10 (1) of Kuwait - Canada BIT provides "A Party shall not nationalize or expropriate covered investments either directly or indirectly through measures having an effect equivalent to nationalization or expropriation (hereinafter referred to as "expropriation") except for a public purpose, in accordance with due process of law, in a non-discriminatory manner and on payment of prompt, adequate and effective compensation." Domestically, Article 19 'Compensation for Expropriation' of the Act regarding the Promotion of Direct Investment in the State of Kuwait states " No Investment Entity, licensed in accordance with the provisions of this Law, shall be confiscated pursuant to this Law nor be deprived of its property except in the public interest and only in accordance with the applicable laws and against compensation equivalent to the true economic value of the expropriated project at the time of expropriation, estimated in accordance with the economic situation prior to any threat of expropriation. The due compensation is to be paid as soon as the said decision is taken." It appears that Kuwait is under two main obligations; one is the compensation against expropriation, second the measures should be taken in a non-discriminatory basis. Discrimination and expropriation are distinct when it comes to their nature as obligations. Health-related measures, therefore, should not be adopted on discriminatory basis first. Second, the expropriation during the course of implementing the measures should be against compensation.

Based on the above - provisions, in the context of direct or indirect expropriation, Kuwait is obliged to compensate investors promptly under BIT and domestic laws when its action amounts to expropriation. The measures adopted by Kuwait raise many questions as to whether they constitute expropriation or trigger compensation.

Second, according to NMP clauses incorporated in most of Kuwait IBTs, they apply either to generally preclude State liability for breaches of substantive treaty protections or as carve-outs only to particular treaty obligations. ${ }^{99}$ However, such clauses may not necessarily relieve the State from the obligation to pay compensation to a foreign investor when their investment is expropriated during a national emergency, or from the obligation not to discriminate when paying compensation. ${ }^{100}$ Other such clauses may not necessarily preclude claims for discrimination. ${ }^{101}$

\footnotetext{
${ }^{99}$ For example, the Belgium-Luxembourg Economic Union-China BIT includes at Art. 4(2) a national and essential security clause that relates only to the provisions on expropriation, and the Japan-China BIT contains in its Protocol a national and essential security clause that relates only to the provisions on non-discrimination.

100 Energy Charter Treaty, Art. 24(1) (“This Article shall not apply to Articles 12, 13 and 29"). See also Energy Charter Treaty, Art. 12.

101 For example; Kuwait - Canada BIT article 10 (1) provides: “A Party shall not nationalize or expropriate covered investments either directly or indirectly through measures having an effect equivalent to nationalization or expropriation (hereinafter referred to as "expropriation") except for a public purpose, in accordance with due process of law, in a non-discriminatory manner and on payment of prompt, adequate and effective compensation."; Kuwait - the Kingdom of Spain BIT Article 5 (1) states: "Investments made by investors of one Contracting Party in the territory of the other Contracting Party shall not be nationalized, expropriated or subjected to direct or indirect measures, such as the
} 


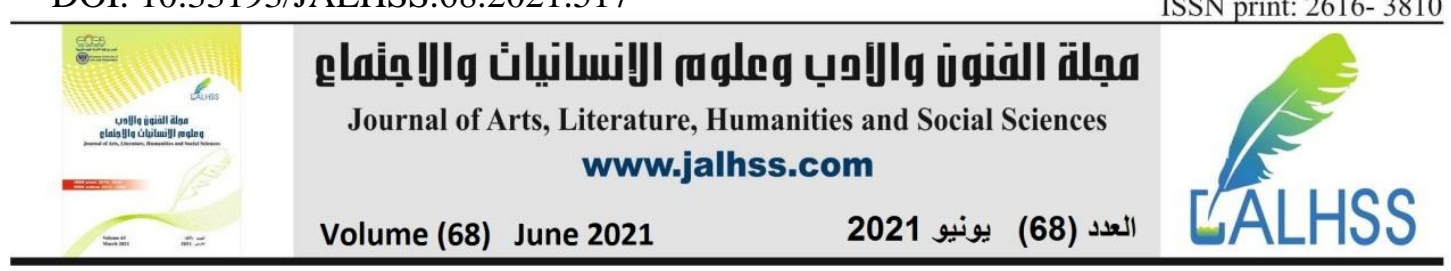

in Feb14 2021, Kuwaiti government announced 1000KD financial support (bailout) to suspended domestic businesses, the act does not consider other foreign investments protected under BITs. ${ }^{102}$ As the government opined, this financial support would be a temporary relief meanwhile they estimate the final compensation. The language of the act clearly specifying Kuwaiti businesses which raise doubts trigger the discrimination claims. The tribunal in Cargill, Inc. v. United Mexican States examined the government's behavior towards the claimant by the considering the treatment given to other industries in same circumstance to determine the discrimination. ${ }^{103}$ In Kuwait - India BIT, Article 7 (1) (a) provides:

Investments made by investors of one Contracting State in the territory of the other Contracting State shall not be nationalized, expropriated, dispossessed or subjected to direct or indirect measures having effect equivalent to nationalisation. expropriation or dispossession (hereinafter collectively referred to as expropriation') b the other Contracting State except for a public purpose related to the internal needs of that Contracting State and against expeditious adequate and effective compensation and on condition that such measures are taken on a non-discriminatory basis and in accordance with the procedure established under law.

Therefore, the act of compensating only Kuwaiti businesses would be taken into account by the tribunal to determine whether there was discrimination.

Third, if investors can prove that there was a proper measures Kuwait could have adopted to avoid the breach of BIT's substantive obligations, the tribunal will rule in favor of the claimant.

Some of the measures Kuwait adopted to prevent the pandemic at the early stage were an airport shutdown which prevented investors from entering the country therefore deprived the investors from their right to manage their investment, also the government suspended all commercial operations ${ }^{104}$. By contrast, the government allowed all Kuwaiti nationals to enter the country as an exception, this might give rise to a breach to fair and equitable treatment. Another step was complete curfew followed by a partial curfew ${ }^{105}$. These measures resulted in a close of the port where

freezing or blocking of investments, having effect equivalent to nationalization or expropriation (hereinafter collectively referred to as "expropriation") by the other Contracting Party except for public purpose and against prompt, adequate and effective compensation and on condition that such measures are taken on a non-discriminatory basis and in accordance with due process of law of general application.".

102 Financial committee report. Available at: https://www.albayan.ae/economy/arab/2021-02-141.4092905 .

103 ICSID Case No. ARB(AF)/05/Z.

104 In March 132020 Kuwait airport announced a shutdown and suspended all commercial operations: https://thepointsguy.com/news/kwi-closes-coronavirus/ (last visit 3 March 2021).

105 In March $22 \quad 2020$ Kuwaiti government implemented nationwide curfew : https://www.garda.com/crisis24/news-alerts/325446/kuwait-government-implements-nationwidecurfew-march-22-update-8 (last visit March 3 2021). 


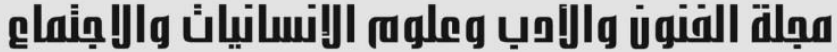 \\ Journal of Arts, Literature, Humanities and Social Sciences www.jalhss.com}

Volume (68) June 2021

يونيو 2021

(68) (لعداد

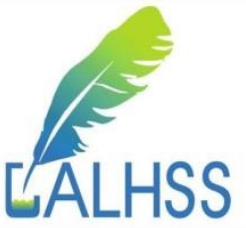

all commodities come through. The government also distributed masks with ration food at lower price which caused the pharmacy sector to loss profit. ${ }^{106}$

Even though Kuwait can expropriate the investment indirectly, but the investor is entitled to a fair compensation.

There might be arguments investors can make: 1) the State measures in pursuant of public health were discriminatory, and therefore cannot be justified on that ground. public health was used as a pretext for another motive in the attempt to justify certain aspects of a State's COVID-19 related measures, such as community pressure (Tecmed v. Mexico) or electoral motivations (Azurix v. Argentina), as would be the case if a State nationalizes airlines, utilities companies, or natural resources industries controlled by foreign investors during COVID-19; 3) State actions worsened the extent of the crisis and therefore harmed the investments at a later time (Azurix v. Argentina); or that 4) States could have adopted measures to fulfill both investment obligations and its obligations to protect the public health (AWG v. Argentina).

\section{Conclusion}

The Covid-19 pandemic has been devastating. Countries have run afoul of their BIT obligations to combat the transmission of the pandemic. The discussion in this article shows that in case of ICSID claims, Kuwait may invoke the necessity defense to justify their Covid-19-related regulatory measures. Security and extreme emergency will likely offer Kuwait grounds to defend its measures as permissible objective. It is also important to bear in mind that Kuwait is bound by both national and international law, to honor the human right to health of its citizens. ${ }^{107}$

\section{References}

1. WHO Coronavirus Disease (COVID-19) Dashboard <https://covid19.who.int/> (last visited 18 Feb 2021).

2. Maryla Maliszewska Aaditya Mattoo and Dominique van der Mensbrugghe, 'The Potential Impact of Covid-19 of GDP and Trade: A Preliminary Assessment, Policy Research' (2020) World Bank Working Paper No. $9211<$ https://open knowledge.worldbank.org/handle/10986/33605> (last visited 18 Feb 2021).

3. Ben Wick, 'The IMF says its forecast for the COVID-19 recession might now be too optimistic' World Economic Forum (18 April 2020) https://www.weforum.org/agenda/2020/04/imf-economy-coronavirus-covid-19-recession (last visited 18 Feb 2021).

4. Adam Payne, 'Spain has Nationalized all of its Private Hospitals as the Country goes into Coronavirus Lockdown' Business Insider (16 March 2020) <https://www.businessinsider.in/politics/news/spain-has-nationalized-all-of-itsprivatehospitals-as-the-country-goes-into-coronavirus-lockdown/articleshow/74658200.cms> (last visited 12 Feb 2021).

${ }^{106}$ https://kuwaitlocal.com/news/government-to-distribute-masks-with-ration-food (last visit March $32021)$.

107 See, International Covenant on Economic, Social and Cultural Rights, art 12.2(c); International Health Regulations 2005. Article 15 of the Constitution of Kuwait 1962 provides that 'The State is responsible for the public health and the means to prevent pandemics". 


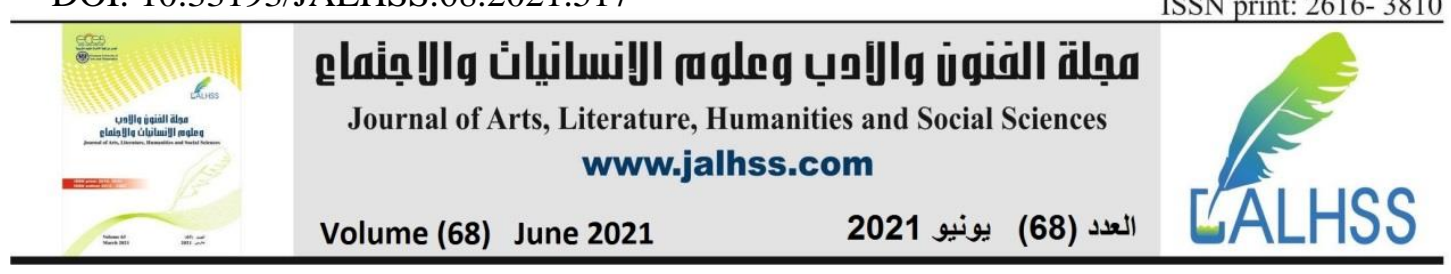

5. Memorandum from President Donald Trump to the Secretary of Health and Human Services (27 March 2020) https://www.whitehouse.gov/presidential-actions/memorandumorder-defence-production-act-regarding-general motorscompany/ (last visited 12 Feb 2021).

6. Oliver Hailes, 'Epidemic Sovereignty? Contesting Investment Treaty Claims arising from Coronavirus Measures' EJIL: Talk! (27 March 2020) $<$ https://www.ejiltalk.org/epidemic-sovereignty-contesting-investment-treaty-claims-arisingfromcoronavirus- measures/> (last visited 12 Feb 2021).

7. Cosmo Sanderson, 'Peru warned of potential ICSID claim over Covid-19 measures' Latin Lawyer (15 April 2020) https://latinlawyer.com/article/1225491/peru-warned-ofpotential-icsid-claims-over-covid-19-measures (last visited 12 Feb 2021).

8. Kuwait Covid-19 restrictions: https://www.garda.com/crisis24/newsalerts/438336/kuwait-several-covid-related restrictions-remain-in-place-in-kuwait-as-of-feb3-update-29. (last visited 16 Feb 2021).

9. The final adopted version of its text looked as follows,

1. Necessity may not be invoked by a State as a ground for precluding the wrongfulness of an act not in

10. conformity with an international obligation of that State unless the act:

(a) Is the only way for the State to safeguard an essential interest against a grave and imminent peril; and

(b) Does not seriously impair an essential interest of the State or States towards which the obligation exists,

11. or of the international community as a whole.

2. In any case, necessity may not be invoked by a State as a ground for precluding wrongfulness if:

(a) the international obligation in question excludes the possibility of invoking necessity; or

(b) the State has contributed to the situation of necessity.

12. Crawford, James, Draft Articles on Responsibility of States for Internationally Wrongful Acts with Commentaries,

13. (2001), 80.

14. Sweet, Alec Stone, Investor-state Arbitration: proportionality's New Frontier, 4 LAW \& ETHICS HuM. RTS, (2010), 47, 69.

15. Ago, Roberto, The Internationally Wrongful Act of the State, Source of International Responsibility, Eighth Report on State Responsibility, Addendum (1980), The ILC Yearbook (1980) Vol. II (1), Doc. A/CN.4/318/Add.5, 5.

16. James Crawford, Second Report on State Responsibility: Addendum, (1999) UN Doc

A/CN.4/498/Add.2, at para

17. 214 [Crawford, Second Report]. Available online at:

http://legal.un.org/ilc/documentation/english/a cn4 498.pdf

(last visited 6 Feb 2021).

18. The Neptune, reprinted in IV International Adjudications: Modern Series 372 (John Basset Moore ed., 1931), citedin Roman Boed, "State of Necessity as a Justification for Internationally Wrongful Conduct", (2000) 3(1) Yale

19. Human Rights and Development Law Journal 1, footnote 28.

20. Ago, Eighth Report, supra (note 14), 39, footnote 117.

21. See, https://www.who.int/news/item/29-06-2020-covidtimeline

22. International Covenant on Economic, Social and Cultural Rights, art 12.2.

23. Gabčíkovo-Nagymaros (n 18) para 55.

24. Crawford, Supra (n 9), 83. 


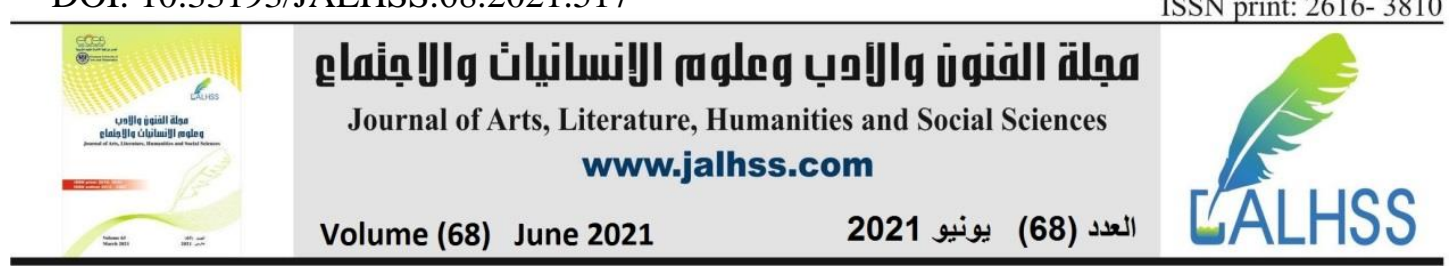

25. See Joost Pauwelyn, The WTO Agreement on Sanitary and Phytosanitary (SPS) Measures as Applied in the First Three SPS Disputes: EC-Hormones, Australia-Salmon and Japan-Varietals, 2 J. INT'L ECON. L.641 (1999).

26. The ILC Yearbook (1980), Vol. II (2), Doc. A/35/10 at 39, para 14 [The ILC Yearbook (1980), Vol. II (2)]. Available online at: http://legal.un.org/ilc/publications/yearbooks/Ybkvolumes(e)/ILC_1980_v2_p2_e.pdf (last visited 15 Feb 2021), 150, para 35.

27. Crawford, James, The International Law Commission's Articles on State Responsibility: Introduction, Text and

28. Commentaries (Cambridge University Press, 2002), 184 [Crawford, ILC Articles],160.

29. Andreas Von Staden, "Towards Greater Doctrinal Clarity in Investor-State Arbitration: The CMS, Enron, and Sempra Annulment Decisions", Law and Economics Research Paper Series, Working paper No. 2010-13 (November 2010), available online: http://ssrn.com/abstract=1725909 (last visited 17 Feb 2021).

30. ICSID Case No.ARB/01/8; Enron Creditors Recovery Corp. Ponderosa Assets. LP v Argentine Republic, (30 July 2010) Decision on Annulment, ICSID Case No.ARB/01/3 [Enron Annulment]; Sempra Energy Int'l v Argentine Republic, (29 June 2010) Decision on Annulment, para36.

31. S.R. Subramanian, "Too Similar or Too Different: State of Necessity as a Defense under Customary International Law and the Bilateral Investment Treaty and their Relationship", (2012) 9 (1) Manchester Journal of International Economic Law, 68, para 133.

32. Case Concerning Oil Platforms (Islamic Republic of Iran v. United States), Judgement, (6 November 2003) Judgement, ICJ, at 196, para 73 [Oil Platforms], available online at: http://www.icj-cij.org/docket/files/90/9715.pdf (last visited $19 \mathrm{Feb} 2021$ ).

33. ${ }^{1}$ See CMS Gas Transmission Co v The Argentine Republic, (25 September 2007) Annulment Decision, ICSID Case No.ARB/01/8.

34. ${ }^{1}$ See ILC, Report of the Study Group of the International Law Commission, Fragmentation of International Law: Difficulties Arising from the Diversification and Expansion of International Law (4 April 2006), Doc. A/CN.4/L.682 [ILC Fragmentation Report], online at: http://legal.un.org/ilc/documentation/english/a_cn4_1682.pdf (last visited 25 Feb 2021).

35. William W. Burke-White, "The Argentine Financial Crisis: State Liability under BITs and the Legitimacy of ICSID System", (2008) 3 Asian Journal of WTO and International Health Law and Policy 199, 206.

36. U.S.-Argentina BIT (1994), Article II, signed 14 November 1991; entered into force 20

October 1994. Available online:

http://investmentpolicyhub.unctad.org/Download/TreatyFile/127.

37. The scope of NPM clauses can also be limited to other treaty provisions such as expropriation or nationalization

38. (Belgian-Luxemburg-China BIT).

39. Uganda - Belgium-Luxembourg BIT (2005), Article 3(2).

40. Barnali Choudhury, "Exception Provisions as a Gateway to Incorporating Human Rights Issues into International Investment Agreements", (2010-11) 49 Columbia Journal of Transnational Law 670, 688.

41. Susan Rose-Ackerman \& Benjamin Billa, "Treaties and National Security", (2008) 40 New York University Journal of International Law and Politics, 437. 


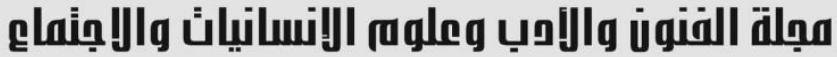 \\ Journal of Arts, Literature, Humanities and Social Sciences www.jalhss.com \\ Volume (68) June 2021 \\ العدد (68) يونيو 2021

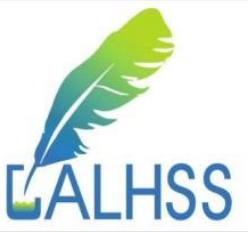

42. See Stephan Schill \& Robyn Briese "If the State Considers: Self-Judging Clauses in International Dispute Settlement", (2009) 13 Max Plank Yearbook of United National Law, 67.

43. U.S.-Bahrain BIT (September 19, 1999), Article 14.

44. Article 18(2), the U.S.-Uruguay BIT (November 4, 2005).

45. LG\&E Energy Corp. v. Argentine Republic, ICSID Case No. ARB/02/1, Decision on Liability, (Oct. 3, 2006), para 214.

46. Newcombe and Paradell, Law and Practice of Investment Treaties: Standards of Treatment (Kluwer Law International BV 2009), 495.

47. Prabhash Ranjan, 'India's International Investment Agreements and India's Regulatory

Power as a Host Nation' (PhD thesis, Kings College, London 2013).

48. WILLIAM W. BURKE-WHITE \& ANDREAS VON STADEN, Investment Protection in Extraordinary Times: The Interpretation and Application of Non-Precluded Measures Provisions in Bilateral Investment Treaties, VIRGINIA JOURNAL OF INTERNATIONAL LAW, Vol 48:2, 361.

49. See Appellate Body Report, European Communities-Measures Affecting Asbestos and Asbestos- Containing Products, IIII 16, 27, WT/DS135/AB/R (Mar. 12, 2001).

50. Agreement on the Application of Sanitary and Phytosanitary Measures., Apr. 15, 1994, Marrakesh Agreement Establishing the World Trade Organization, Annex 1A, 1867 U.N.T.S. 493, available at http://www.wto.org/English/tratop_e/sps_e/spsagr_e.htm (last visited $15 \mathrm{Feb}$ 2021).

51. See, Joost Pauwelyn, The WTO Agreement on Sanitary and Phytosanitary (SPS) Measures as Applied in the First Three SPS Disputes: EC-Hormones, Australia-Salmon and Japan-Varietals, 2 J. INT'L ECON. L.641 (1999).

52. See Appellate Body Report, European Communities-Measures Concerning Meat and Meat Products (Hormones), 116-19, WT/DS26/AB/R \& WT/DS48/AB/R (Jan. 16, 1998)

53. Appellate Body Report, Japan-Measures Affecting Agricultural Products, 84, WT/DS76/AB/R (Feb. 22, 1999).

54. See Appellate Body Report, European Communities-Measures Concerning Meat and Meat Products (Hormones), 116-19, WT/DS26/AB/R \& WT/DS48/AB/R (Jan. 16, 1998)

55. Letter of Transmittal, U.S.-Kyrgyzstan BIT, Article X, January 19, 1993, S. Treaty Doc. No. 103-13. Available online at: http://www.state.gov/documents/organization/43567.pdf (last visited 9 Feb 2021).

56. Catherine Kessedjian, "Public Order in European Law", (2007) 1 Erasmus Law Review $25,26$.

57. MJB Bernier, "Droit Public and Ordre Public", (1929) 15 Transactions of the Grotius Society 83 ,

58. Philip Morris Brands Sàrl, Philip Morris Products S.A. and Abal Hermanos S.A. v. Oriental Republic of Uruguay, ICSID Case No. ARB/10/7, Award (July 8, 2016), IIII 306, 420, 434.

59. Philip Morris Brands Sàrl, Philip Morris Products S.A. and Abal Hermanos S.A. v. Oriental Republic of Uruguay, ICSID Case No. ARB/10/7, Award (July 8, 2016), II 399.

60. Philip Morris Brands Sàrl, Philip Morris Products S.A. and Abal Hermanos S.A. v. Oriental Republic of Uruguay, ICSID Case No. ARB/10/7, Written Submission (Amicus Curiae Brief) by the World Health Organization and the WHO Framework Convention on Tobacco Control Secretariat (Jan. 28, 2015). 


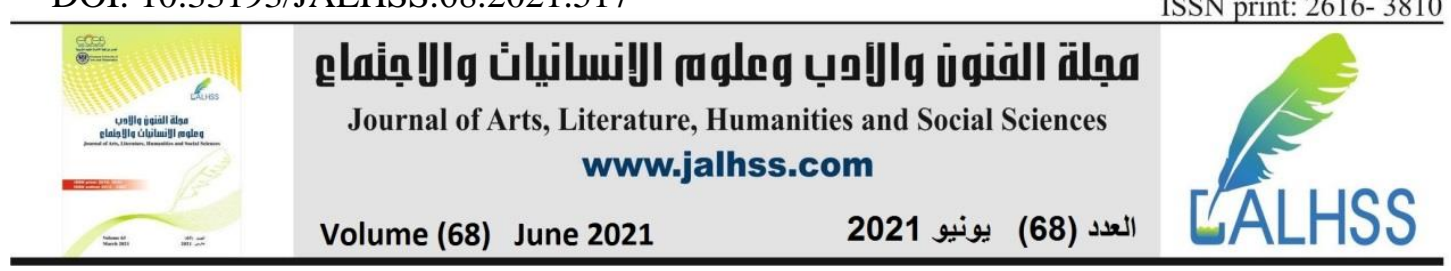

61. See, e.g., Crompton (Chemtura) Corp. v. Government of Canada, UNCITRAL, Award (Aug. 2, 2010), 266; Apotex Holdings Inc. and Apotex Inc. v. United States of America, ICSID Case No. ARB(AF)/12/1, Award (Aug. 25, 2014), II 8.75.

62. https://www.garda.com/crisis24/news-alerts/445301/kuwait-authorities-amend-covid-19entry-restrictionseffective-feb-21-update-31

63. See TECNICAS MEDIOAMBIENTALES TECMED S.A. v.THE UNITED MEXICAN STATES, case No. ARB (AF)/00/2, May 29, 2003.

64. Tim K. Mackey \& and Bryan A. Liang, "Lessons from SARS and H1N1/A: Employing a WHO-WTO forum to promote optimal economic-public health pandemic response The continuation of the measures should be based on scientific opinion", Journal of Public Health Policy Vol. 33, 1, 119-130.

65. Nouf Almazidi, Kuwait COVID-19 Business Impact Survey Finds 45\% of Businesses have Shut Down Since February, available at: https://www.prnewswire.com/newsreleases/kuwait-covid-19-business-impact-survey-finds-45-of-businesses-have-shut-downsince-february-301060491.html (last visit March 6 2021).

66. Philip Morris Brands Sàrl, Philip Morris Products S.A. and Abal Hermanos S.A. v. Oriental Republic of Uruguay, ICSID Case No. ARB/10/7, Award (July 8, 2016), TIII 306, 420, 434.

67. Philip Morris Brands Sàrl, Philip Morris Products S.A. and Abal Hermanos S.A. v. Oriental Republic of Uruguay, ICSID Case No. ARB/10/7, Award (July 8, 2016), II 399.

68. Philip Morris Brands Sàrl, Philip Morris Products S.A. and Abal Hermanos S.A. v. Oriental Republic of Uruguay, ICSID Case No. ARB/10/7, Written Submission (Amicus Curiae Brief) by the World Health Organization and the WHO Framework Convention on Tobacco Control Secretariat (Jan. 28, 2015).

69. See, e.g., Crompton (Chemtura) Corp. v. Government of Canada, UNCITRAL, Award (Aug. 2, 2010), 266; Apotex Holdings Inc. and Apotex Inc. v. United States of America, ICSID Case No. ARB(AF)/12/1, Award (Aug. 25, 2014), 8.75.

70. For example, the Belgium-Luxembourg Economic Union-China BIT includes at Art. 4(2) a national and essential security clause that relates only to the provisions on expropriation, and the Japan-China BIT contains in its Protocol a national and essential security clause that relates only to the provisions on non-discrimination.

71. Energy Charter Treaty, Art. 24(1) ("This Article shall not apply to Articles 12, 13 and 29"). See

72. Financial committee report. Available at: https://www.albayan.ae/economy/arab/202102-14-1.4092905.

73.International Covenant on Economic, Social and Cultural Rights, art 12.2(c); International Health Regulations 2005. Article 15 of the Constitution of Kuwait 1962 provides that 'The State is responsible for the public health and the means to prevent pandemics". 